\title{
Japan's Human Frontiers project stays in the doldrums
}

\section{Tokyo}

THE future of the Human Frontiers Science Programme, Japan's attempt to forge an international programme of longterm research, seems suddenly to be clouded, in the wake of the last month's economic summit at Venice.

Officials of the Agency of Industrial Science and Technology of the Ministry of International Trade and Industry (MITI) have been working for the past two years on this ambitious project, which is aimed at creating new technology through the study of biological functions. Voluminous reports have been produced, and there have been three meetings with scientists of the summit nations, one of them in London on 1 April (Nature 326, 8; 1987).

The definition of the intended research programme nevertheless remains stubbornly unclear. Even the staunchest ally of the Human Frontiers project, Prime Minister Yasuhiro Nakasone, criticized the programme as "too vague" when given a draft text to present at the Venice summit meeting. And while the Human Frontiers project achieved a mention at the end of the Venice declaration, participants merely welcomed the initiative, thanked Japan for the opportunities provided for participation in discussions of the programme, noted that the feasibility study was to continue and asked to be kept informed of progress. A commitment to participate in the proposed programme was conspicuous by its absence.

MITI officials say that the Venice summit was "quite successful", although Katsuhiko Umehara, MITI's deputydirector of the programme, admits that the programme is in a "chicken-and-egg situation". If there is no commitment on participation from other summit nations, the Ministry of Finance is unlikely to provide the funds needed for the programme. But other nations are unlikely to join until Japan itself comes forward with a substantial financial committment to its own programme.

So what is the next step? Umehara says that an "international feasibility study" will be started later in the year, probably in September, with the help of Y150 million (about $\$ 1$ million) of funds already provided in this year's budget. Before then, MITI and the Science and Technology Agency, which is also involved in the Human Frontiers Programme, will be required to submit their budget requests for the succeeding financial year, when they will have to give some plan for the continuation of the project.

This is the first issue of Nature to be printed in Japan.
Umehara says that MITI and the agency may put forward a "pilot programme" for 1988 , incorporating a few typical components of Human Frontiers. Among the projects being considered, he says, is the non-invasive measurement of magnetic fields in the brain using a direct-current SQUID, which would be undertaken by Dr Hisashi Kado's group at MITI's Electrotechnical Laboratory at Tsukuba. Umehara also mentions in this connection the Science and Technology Agency's plan to sequence the human genome (Nature 326, 323; 1987).

The Science and Technology Agency, on the other hand, seems to have other views. Masahiro Kawasaki, deputy director-general of the agency's Research and Development Bureau which has charge of the genome project, says that the agency will proceed separately from the Human Frontiers project in 1988 because the human genome project is an urgent matter in which Japan has an agreement on coordinated action with the US Department of Energy, whereas the Human Frontiers project is, at this stage, only a feasibility study. If the Human Frontiers programme is eventually realized, he said, the human genome project could then be incorporated within it.

The essential difficulty in carrying through the planning of the Human Frontiers project seems to be the large numbers of agencies with a finger in the pie. The project was born in the Agency of Industrial Science and Technology in response to the criticism that Japan gets a free ride in technology that springs from basic research in the West.

But the project has grown into a bureaucratic monster involving several ministries and an army of academic advisers inclined to wait and see (which may not be surprising, given that they had not thought of the programme in the first place). One person who could lead the project forward is Prime Minister Nakasone, but he is due to retire in October and none of his potential successors shares his interest in the life sciences.

The fate of the Human Frontiers project should become clear at the end of next month, when the ministries will put forward their budget proposals. David Swinbanks

\section{Sodium leak threatens French nuclear power programme}

\section{Paris}

A LEAK of liquid sodium from a storage tank at the world's largest fast-breeder reactor, Superphénix at Creys-Malville near Lyons, may jeopardize the planned expansion of France's nuclear energy programme. While there seems to be no immediate environmental danger, finding and repairing the leak could take $2-3$ years and cost an estimated FF400 million ( $£ 40$ million). Growing disaffection from nuclear energy among the French public will make the government's handling of the incident a sensitive issue during the run-up to next year's presidential elections.

Meanwhile, the leak will be used as ammunition for those critics who say that the prototype Superphenix, designed to produce 1,242 MW of electricity, was a poor investment. It may also stymie the plans of Electricité de France (EDF) to build a sister reactor, Superphénix-2.

The leak at Creys-Malville was first detected in March this year, when sodium began leaking into the space between the tank and its outer protective shell at the rate of 500 litres a day. Although the leak stopped of its own accord some weeks later, on 25 June it reappeared, at a rate of 800 litres a day. Engineers are now sure there is a 1-mm hole in the base of the tank. Either the sodium will have to be drained from the tank or the whole tank will have to be replaced.
The immediate question to be decided by energy minister Alain Madelin is whether the reactor can continue to function with the tank out of action. Although not part of the steam-raising circuit, the tank is used for storing spent fuel rods removed from the reactor. Experts at EDF argue that, as the new fuel rods being installed during the current maintenance period have a working life of 400 days, they would last long enough for the tank to be drained and repaired. A report being prepared by EDF should allow a decision to be reached at the end of August.

Part of the trouble descending on the French government is a consequence of its handling of the Chernobyl accident last year. At first, the information put out by the official body responsible for radiological safety claimed that the radioactive cloud had avoided France. When it became clear that this was not the case, people began to question the statements on nuclear safety issued by the government. Since then, mounting criticism of French nuclear policy from neighbouring countries has affected public opinion. West German complaints of pollution of the Mosel river by the French Cettenom reactor is causing an outcry, while there has been a decline of the public support for nuclear energy, within France itself, on which the expansionist nuclear programme depends.
Peter Coles 